\title{
ANALISIS INSTAGRAM SEBAGAI SOCIAL MEDIA MARKETING DI INDUSTRI PERHOTELAN
}

\author{
Oleh \\ Elysa Nur Cahyani ${ }^{1)}$, Dewi Pancawati $\mathbf{N}^{2)}$ \& Endah Fitriyani ${ }^{3)}$ \\ 1,2,3 Universitas Pendidikan Indonesia Bandung \\ Email: ${ }^{1}$ elysanurcahyani2000@upi.edu, 230novalita@gmail.com \& \\ 3endahfitriyani@upi.edu
}

\begin{abstract}
Abstrak
Pemasaran melalui sosial media Instagram memberikan peluang bagi konsumen untuk berinteraksi lebih baik dengan industri perhotelan, hal ini juga memiliki efektivitas biaya yang lebih besar, selain itu aplikasinya semakin banyak fitur-fitur unik yang bermunculan sehingga memudahkan pemasar untuk berkreasi semenarik mungkin. Kemunculan Instagram dengan fitur-fitur unik dan dapat diakses di seluruh dunia ini mendorong industri perhotelan menggunakannya untuk memasarkan produk serta memberikan peluang bagi konsumen untuk berinteraksi lebih baik dengan perusahaan sehingga memiliki efektivitas yang lebih tinggi. Tujuan dari penelitian ini ntuk megeksplorasi mengenai alasan industri perhotelan menggunakan Instagram sebagai media pemasaran serta topik yang sering diteliti pada jurnal sebelumnya mengenai penerapan Instagram sebagai social media marketing di industry perhotelan. Metode yang digunakan adalah kualitatif dengan pendekatan systematic literature review untuk menemukan teori yang relevan tentang topik ini kemudian diidentifikasi, dinilai, dan disintesis menurut metode eksplisit yang telah ditentukan sebelumnya sehingga pendekatan SLR memberikan kejelasan, transparansi dan ketidakberpihakan serta cakupan yang inklusif di wilayah tertentu. Hasil penelitian ini adalah hotel menggunakan sosial media Instagram sebagai pemasarannya karena Instagram memiliki banyak fitur seperti hashtag dan instastory yang dapat menjangkau audiens secara luas. Selain itu, postingan dalam format gambar juga berdampak besar pada keputusan pelanggan. Namun, ini bukanlah kekuatan pemasaran Instagram sepenuhnya. Disisi lain, penelitian yang sering dilakukan sebelumnya adalah mengenai penerapan sosial media marketing di hotel.
\end{abstract}

\section{Kata Kunci: Perhotelan, Social media marketing \& Instagram}

\section{PENDAHULUAN}

Pada era sekarang ini, industri perhotelan semakin banyak dan luas sehingga mempertahankan industri agar tetap bertahan untuk memajukan pariwisata ini sangatlah tidak mudah. Sejalan dengan jurnal yang diteliti oleh Hasliza Hassan, menjelaskan bahwa industri perhotelan sangat penting sebagai penyokong dalam mepertahankan stabilitas pariwisata di berbagai negara belahan dunia (Hassan, 2018). Oleh karena itu, setiap industri perhotelan harus membuat strategi pemasaran agar bisa menarik konsumen baru atau mempertahankan konsumen lama dengan memberikan apa yang dibutuhkan konsumen. Program pemasaran yang efektif dan efisien merupakan solusi untuk memuaskan tamu dengan memberikan kualitas pelayanan dan juga menawarkan utilitas tambahan untuk memfasilitasi kebutuhan tamu (Dabrowski, 2019).

Baru-baru ini pemasaran yang efektif dan efisien sangat mencuri perhatian masyarakat dan dinilai memiliki peluang bisnis agar tujuan pemasaran mereka tercapai dan sangat rendah biaya yaitu dengan mengadopsi pemasaran media sosial. Platform media sosial memberikan peluang besar bagi bisnis untuk mencapai tujuan pemasaran mereka dengan biaya yang sangat rendah dan juga pemasaran media sosial semakin mendapat perhatian di kalangan industri perhotelan (Ajina, 2019). Pemasaran melalui sosial media ini bisa memberikan keuntungan yang signifikan terutama bagi industri perhotelan dengan 
menghubungkan konsumen pada industri perhotelan tersebut. Bererapa keuntungan menggunakan pemasaran melalui media sosial ini yaitu memungkinkan perusahaan selalu terhubung dengan pelanggan kapan dan dimanapun sehingga dapat meningkatkan brand awareness , pengaruh sikap konsumen, menerima umpan balik, membantu meningkatkan produk dan layanan baru, serta meningkatkan penjualan (Dwivedi, 2020)

Manfaat yang bisa dirasakan oleh industri perhotelan adalah karena media sosial merupakan alat pemasaran yang digunakan oleh jutaan orang didunia dan cakupan media sosial sangat luas. Jumlah pengguna media sosial yang banyak dan cakupan yang luas seperti data pribadi pelanggan, penawaran dan permintaan serta pendapat pelanggan mewakili sumber informasi yang berharga untuk melakukan pemasaran melalui sosial media (Arrigo, 2018). Selain menjadi alat yang digunakan sebagai pemasaran dan periklanan, media sosial juga digunakan sebagai penghubung antar konsumen untuk saling berbagi informasi. Media sosial juga menghubungkan setiap pengguna untuk berbagi konten, interaksi, dan diskusi online mengenai berbagai produk pariwisata khususnya perhotelan, sehingga mereka bisa mencari, mengevaluasi, memberi peringkat, dan membeli produk perhotelan dengan mudah melalui sosial media (Gupta, 2019). Sekarang ini, sosial media telah menjadi bagian dari kehidupan sehari-hari bagi jutaan orang di seluruh dunia. Dapat dibuktikan dengan data pengguna media sosial di seluruh dunia dari tahun 2016 hingga 2021 pada Gambar 1.1 menurut Statista (2021).

Gambar 1. Data Pengguna Sosial Media Di Dunia Tahun 2016-2021

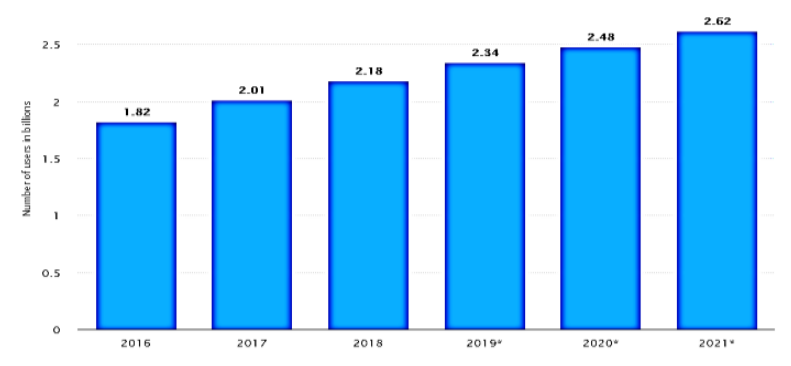

Dari gambar diatas dapat diketahui bahwa pengguna media sosial setiap tahunnya terus bertambah sehingga tidak mengherankan bahwa hotel meningkatkan aktivitasnya di media sosial untuk tujuan pemasaran dan keterlibatan konsumen. Terdapat banyak platform media sosial yang digunakan indistri perhotelan untuk melakukan pemasaran seperti seperti Instagram dan Twitter, youtube, dan tripadvisor (Kang, 2018). Dibandingkan dengan platform media sosial lainnya, Instagram memiliki daya tarik yang lebih tinggi karena menawarkan lebih banyak tindakan yang bisa dilakukan dan juga menunjukkan bahwa konsumen lebih sering berbelanja di instagram setelah melihat postingannya. Beberapa industri perhotelan memilih instagram karena menawarkan lebih banyak tindakan yang bisa dilakukan seperti memposting konten berupa foto,video, cerita yang menyenangkan, estetika, kreatif, dan menawan dengan fokus pada kualitas visual dan untuk memamerkan produk mereka dengan cara yang menarik (Casaló, 2018) serta konsumen cenderung lebih sering berbelanja di Instagram setelah berinteraksi dengan postingan dari akun merek tertentu dan keterlibatan postingan pada platform ini jauh lebih tinggi dibandingkan dengan Facebook atau Twitter. (Vinerean \& Opreana, 2019).

Banyaknya kelebihan dan daya tarik yang lebih tinggi dibandingkan dengan platform lain, menjadikan Instagram sebagai platform yang banyak digunakan oleh orang di dunia sebagai alat untuk melakukan pemasaran dan terus berkembang setiap tahunnya. Hal tersebut sesuai dengan Gambar 1.2 mengenai data pengguna Instagram pada tahun 2021 yang mencapai 909,8 juta orang yang dikutip dari Statista sejak tahun 2016-2023 
Gambar 2. Data Pengguna Instagram Di Dunia Tahun 2016-2023

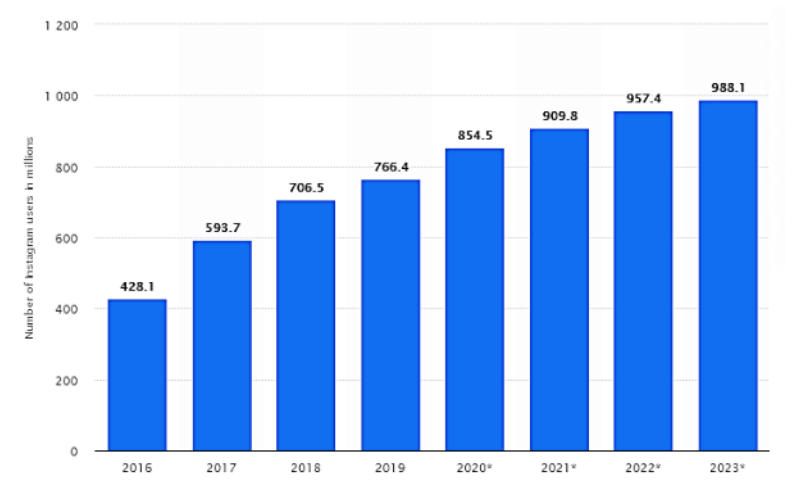

Banyaknya pengguna Instagram melandasi setiap industri perhotelan untuk melakukan pemasaran melalui platform ini karena Instagram dapat bertindak sebagai jembatan antara industri perhotelan dengan konsumennya untuk membantu berinteraksi satu sama lain melalui online untuk berbagi informasi dan pendapat mereka tentang hotel. Instagram telah menjadi sumber pemasaran produk perhotelan yang memuat berbagai informasi seperti, kamar, sarapan, makan siang dan prasmanan, spa, dan fasilitas lain kepada konsumen sehingga mereka dapat berinteraksi secara mudah melalui situs media sosial ini (Parvez, 2018).

Media sosial instagram telah mendapatkan banyak popularitas sehingga dapat meningkatkan minat pemasar terhadap hal ini, selain itu platform yang kaya visual dan kreatif telah menjadi alat yang ampuh untuk pemasaran yang berfokus pada pembuatan dan pendistribusian konten secara konsisten sehingga dapat mendorong pelanggan yang menguntungkan karena kemampuannya untuk menampilkan layanan atau tujuan dan terhubung dengan perusahaan. Konten di Instagram lebih tinggi keterlibatan dibandingkan platform lain. Instagram adalah salah satu platform media sosial terbesar yang terkonsentrasi pada komunikasi visual dan konten di Instagram lebih tinggi keterlibatan dibandingkan platform lain, selain itu juga tidak spanduk yang mengganggu seperti di Facebook (Tertunen, 2017).

Media visual Instagram juga memiliki dampak yang sangat besar pada perilaku pembelian konsumen karena memberikan wadah bagi konsumen untuk membuat hubungan visual dengan produk sebelum mereka membeli, selain itu konten video juga dapat digunakan untuk berkomunikasi dan menjangkau pengguna di Instagram karena Video konten meningkat di Instagram dan dengan pengenalan fungsi cerita, berbagi video semakin populer di kalangan pengguna. Foto adalah bagian besar dari perjalanan pemasaran dan aspek visual mengambil peran utama dalam komunikasi pemasaran, itulah sebabnya Instagram harus menjadi bagian dari rencana pemasaran (Gretzel 2016).

Oleh karena itu, instagram dianggap sebagai salah satu media sosial yang paling cocok bagi hotel untuk berkomunikasi dengan penggunanya dan mengembangkan hubungan yang efektif dan intensif dalam kegiatan promosi dan pemasaran agar mendapatkan keuntungan kompetisi. (Undey et al. 2019). Hal ini dapat mengurangi ketergantungan bisnis hotel bisnis pada biro perjalanan, dan memberikan kesempatan untuk memberikan informasi terkini tentang hotel secara langsung dan interaktif dengan pelanggan dengan cara yang cepat, murah, dan instan.

Berdasarkan pemaparan diatas dan dengan adanya beberapa penelitian sebelumnya yang telah peneliti kaji, terdapat satu jurnal acuan yang berfokus mengkaji penggunaan media sosial dalam pemasaran pariwisata dan perhotelan (Chenglin, 2020) dalam penelitian tersebut menjelaskan saran untuk penelitian selanjutnya yaitu untuk membedakan dan menguraikan fungsi dari media sosial yang berbeda yang digunakan untuk pemasaran pariwisata dan perhotelan dan bagaimana pengaruhnya terhadap industri tersebut (Chenglin, 2020). Selain itu, terdapat jurnal pendukung yang mengkaji penggunaan sosial media sebagai alat pemasaran yang berfokus pada platform twitter (Alansari, 2018 ; Curlin, 2019, Kim, 2018) dan facebook (kang, 2018 ; Lo\&Fang, 2018 ; Desilva, 2019; ; Sabapathy, 2018). Dengan demikian, peneliti mencoba untuk mengisi celah penelitian dengan mengkaji mengenai pemasaran pada platform Instagram dikarenakan platform tersebut telah 
berkontribusi banyak dalam pemasaran bisnis perhotelan. Hal ini dikuatkan dengan data yang menyebuttkan terdapat $82 \%$ brand atau pebisnis di Indonesia menerima Pesan Langsung Instagram dari pelanggan mereka setiap hari, dan 87\% dari Mereka sepakat berhasil meningkatkan penjualan setelah melakukan aktivitas pemasaran di Instagram. Di sisi lain, 90\% pengguna Instagram mengatakan bahwa mereka telah berkomunikasi dengan merek di Instagram (Aji, 2020). Pemasaran melalui sosial media Instagram ini sangat penting memberikan peluang bagi konsumen untuk berinteraksi lebih baik dengan perusahaan, hal ini juga memiliki efektivitas biaya yang lebih besar, selain itu aplikasinya semakin banyak fitur-fitur unik yang bermunculan sehingga memudahkan pemasar untuk berkreasi semenarik mungkin. Kemunculan Instagram dengan fitur-fitur unik dan dapat diakses di seluruh dunia ini mendorong perusahaan menggunakannya untuk memasarkan produk serta memberikan peluang bagi konsumen untuk berinteraksi lebih baik dengan perusahaan sehingga memiliki efektivitas biaya yang lebih tinggi (Amelia \& Hidayatullah, 2020).

Maka dari itu, peneliti mencoba untuk mengisi celah penelitian dengan mengkaji mengenai "Analisis Instagram sebagai Social Media Marketing di Industri Perhotelan" menggunakan Systematic Literature Review sebagai metode penelitiannya.

\section{LANDASAN TEORI}

Dalam bab ini peneliti akan membahas tentang teori dan literasi pendukung serta beberapa penelitian yang terkait untuk penelitian ini. Dengan mengusung tema Konsep Pemasaran dan Instagram. Tema tersebut kemudian dikembangkan pada bab ini untuk menghasilkan kajian pustaka yang peneliti harapkan.

\section{Konsep Pemasaran}

Pada Sub bab ini peneliti akan menjelaskan beberapa bahasan mengenai konsep pemasaran sebagai kajian pendukung yaitu pemasaran dalam industry perhotelan dan Social Media marketing pada pemasaran hotel

\subsection{Perkembangan Alat Komunikasi} Pemasaran dalam Industri perhotelan

Pemasaran merupakan beberapa rangkaian proses untuk mempromosikan suatu produk atau jasa kepada konsumen dan juga mempertahankan stakeholder yang lainnya. Sedangkan menurut Kaptan Ugurlu dan American Marketing Association (AMA) bahwa pemasaran adalah suatu proses yang dilakukan dari awal barang tersebut dibuat sampai, mendukung dan memberi harga produk atau layanan, dan bagaimana cara untuk mempromosikannya kepada pelanggan sebaik mungkin agar dapat mempertahankan interaksi dengan pemangku kepentingan dalam lingkungan pemasaran tersebut (Sadq, Othman, \& Khorsheed, 2019 ; Ugurlu, 2021).

Oleh karena itu, para pemasar khususnya pada industri pehotelan melakukan pemasaran dengan menggunakan beberapa alat periklanan untuk mengkomunikasikan produk atau jasanya kepada konsumen dengan baik dan benar agar bisa menghasilkan keuntungan bagi perhotelan tersebut. Inilah sebabnya megapa banyak pemasaran pada hotel yang menggunakan alat seperti periklanan untuk mempromosikan dan mengkmunikasikan produk atau jasanya agar menghasilkan keuntungan yang lebih besar dan juga memberikan dampak positif bagi perusahaan serta konsumen (Nicolaides, 2018).

Komunikasi pemasaran dan media periklanan juga telah mengalami transformasi sejak diluncurkannya beberapa teknologi baru yang membuat perusahaan dan konsumennya lebih nyaman dalam berkomunikasi. Media baru, seperti Internet, media sosial, dan ponsel semakin menggantikan media massa tradisional dan dalam industry perhotelan sangat berpengaruh pada proses pengambilan keputusan konsumen dan niat pemesanan (Leung et al., 2017).

Pemasaran di industry perhotelan juga dilakukan bukan hanya untuk menarik pelanggan yang sudah loyal, tetapi juga untukk menarik pelanggan baru. Dikutip dari jurnal 
Thwala \& slabbert (2018) Agar pemasaran berjalan dengan baik maka pendekatan integral diperlukan di mana industry tersebut tidak hanya menjual produk kepada pelanggan yang sudah ada, tetapi juga mencoba untuk menjual kepada orang baru (Kotler \& Armstrong, 2010:19).

\section{Digital Marketing dalam Industri Perhotelan}

Sudah diketahui secara luas bahwa setiap bidang bisnis baik skala kecil atau besar terus beradaptasi dengan perubahan teknologi yang semakin canggih dan menyebabkan terjadinya inovasi dalam menciptakan model bisnis baru dan kemampuan untuk memberikan layanan premium dengan cara yang baru. Teknologi juga telah menjadi pendorong utama bisnis khususnya di bidang perhotelan dan secara drastis telah mengubah cara beroperasi dan kinerja industri tersebut (Adeyinka-Ojo et al., 2020)

Teknologi yang berkembang di industri perhotelan saat ini seperti internet dan teknologi digital lainnya banyak digunakan untuk mendukung, meningkatkan, dan mengoptimalkan berbagai proses bisnis, termasuk pemasaran sehingga sering disebut sebagai pemasaran digital. Istilah pemasaran digital menggambarkan ruang lingkup kegiatan yang lebih luas daripada pemasaran Internet dan pemasaran web yaitu mengacu pada berbagai platform digital untuk berinteraksi dengan pengguna, manajemen data pelanggan digital, dan manajemen hubungan pelanggan secara elektronik (Mahmutović, 2021).

Oleh karena itu, sangat penting bagi industri perhotelan untuk membuat rencana pemasaran digital, dan mengelola platform digital dengan beberapa komponen pemasaran. Pemasaran digital di hotel mempunyai komponen utama yaitu hotel dapat secara aktif menggunakan informasi digital dalam upaya pemasarannya dan hotel dapat memiliki file percakapan pelanggan atau komentar tamu untuk membuat strategi manajemen (Pelsmacker et al., 2018).

Namun, menurut Wibisono meskipun perkembangan teknologi dan informasi dalam bisnis bergerak menuju ekonomi digital yang menciptakan berbagai macam kenyamanan dan kemudahan dalam mengakses informasi melalui internet, namun konsep pemasaran digital juga harus menggabungkan pemasaran secara online dengan offline antara perusahaan dan pelanggan. Interaksi digital saja tidak cukup meskipun dunia online sangat berkembang, sehingga harus diimbangi oleh pemasaran secara offline dan hubungan antar manusia karena teknologi ini hanya berguna untuk membangun perangkat dan system (Wibisono, 2019).

\section{Inovasi Digital melalui Sosial Media Marketing di Perhotelan}

Perubahan pada era digital membuat inovasi yang baru bagi pemasaran di suatu perusahaan yaitu dengan munculnya pemasaran pada sosial media atau perangkat seluler sehingga pelanggan bisa berinteraksi dengan perusahaan melalui media sosial atau perangkat seluler tersebut. Transformasi digital pada perusahaan khususnya industry perhotelan ini mengubah sarana komunikasi pemasaran dalam beberapa tahun terakhir yang menyebabkan munculnya saluran baru dalam pemasaran misalnya penggunaan media sosial atau perangkat seluler sehingga mengubah praktik pemasaran dengan cara yang lebih praktis yaitu pelanggan bisa berbelanja dan berinteraksi dengan perusahaan menggunakan saluran ini (Kalaignanam, 2020).

Munculnya jaringan media sosial adalah salah satu perkembangan Web 2.0 yang telah mengubah cara hotel dalam berkomunikasi dengan pelanggan secara lebih menarik, berpusat pada pengguna, dan transparan. Jaringan media sosial juga dapat membantu tamu hotel sebagai referensi dengan melihat konten yang dibuat konsumen ataupun pihak hotel itu sendiri di media sosial sehingga sering dipercaya dan dianggap meredakan ketidakpastian dalam melakukan pembelian oleh konsumen (Jung et al., 2018)

Perubahan sarana komunikasi pemasaran ini menyebabkan banyaknya platform sosial media yang bermunculan yang dimanfaatkan oleh beberapa perusahaan untuk mendorong industry pariwisata mereka khusunya pada perhotelan untuk memberikan 
informasi yang memadai mengenai produk dan layanan yang mereka sediakan melalui sosial media. Perkembangan sarana komunikasi ini menyebabkan munculnya beberapa aplikasi di sosial media yang berkontribusi untuk mengubah metode konvensional dalam pemasaran dan pariwisata yang bisa memberi keuntungan dalam memberikan informasi yang spesifik seperti informasi tentang perjalanan, harga, dan layanan yang ditawarkan dengan cara yang menarik dan lebih mudah (Alghizzawi \& habes, 2018).

Media sosial ini merupakan suatu aplikasi yang bisa digunakan untuk berkomunikasi antar pengguna melalui media online, serta banyak digunakan oleh perusahaan yang baru sebagai media pemasarannya. Platform media sosial adalah aplikasi online yang memungkinkan para penggunanya bersosialisasi dengan membagikan konten secara digital dan sebagian besar perusahaan yang baru berkembang membuat media sosial sebagai platform periklanannya (Chu, deng, \& cheng, 2020).

Selain itu, media sosial juga tidak hanya digunakan untuk berkomunikasi antar pengguna tetapi juga bisa digunakan oleh perusahaan dan pengguna agar bisa menjalin hubungan baru sehingga meningkatkan kepuasan pelanggan dan loyalitas pelanggan. Media sosial dapat meningkatkan komunikasi dua arah antara perusahaan dan pelanggan dengan menampilkan konten secara visual, tekstual, verbal atau menggunakan campuran ketiganya sehingga semakin meningkatkan keterlibatan konsumen dengan perusaan dan dapat meningkatkan kepuasan pelanggan serta loyalitas pelanggan (Mohammed, 2019).

Semakin banyak keterlibatan konsumen dengan perusahaan akan mempersepsikan manfaat dan kemudahan dalam menggunakan jasa pada aplikasi media sosial, sehingga semakin besar kemungkinan mereka berbelanja melalui media sosial. Penggunaan Media Sosial mempunyai peran mendasar terhadap social media marketing karena orang menggunakan lebih banyak aplikasi media sosial sehingga sikap mereka terhadap pemasaran media sosial menjadi lebih positif sehingga hotel juga harus memperhatikan layanan yang ditawarkan melalui media sosial agar penggunanya dapat melakukan pembelian (Theocharidis, 2019).

Instagram sebagai alat pemasaran di industri perhotelan

Instagram didirikan pada tahun 2010 oleh 2 orang programmer handal di San Fransisco, California yaitu Kevin Systrom dan Mike Krieger di San Francisco. Pada awalnya Instagram secara resmi diluncurkan secara eksklusif untuk iPhone pada 6 Oktober 2010 dengan nama asli dari aplikasinya adalah Burbn, yang bertujuan untuk menggabungkan beberapa karakteristik layanan media sosial populer seperti Foursquare dan berfokus pada gambar (Nuryadin et al., 2020).

Pada tahun 2013, Instagram masih aplikasi yang sangat baru bagi pengguna sehingga masih jarang digunakan dibandingkan dengan Twitter dan Facebook yang disukai oleh pengguna remaja. Namun, pada tahun 2014 Instagram menjadi jejaring sosial terpenting; sekitar $13 \%$ peningkatan pengguna Instagram pada tahun 2014 dibandingkan dengan tahun 2013. Instagram adalah sosial media yang sering digunakan sehingga menunjukkan angka $30 \%$ dibandingkan dengan Twitter pada 27\% dan Facebook pada 25\%. Tidak hanya berhenti disitu, Instagram juga tetap menjadi sosial media banyak digunakan dengan persentase yang tertinggi dibandingkan dengan Twitter dan Facebook berikut dikutip dari jurnal (Le, 2018) Berikut grafik pengguna Instagram pada tahun 2013 dan 2014 yang didapat dari jurnal Le.

Gambar 3. Pengguna instagram pada tahun 2013-2014

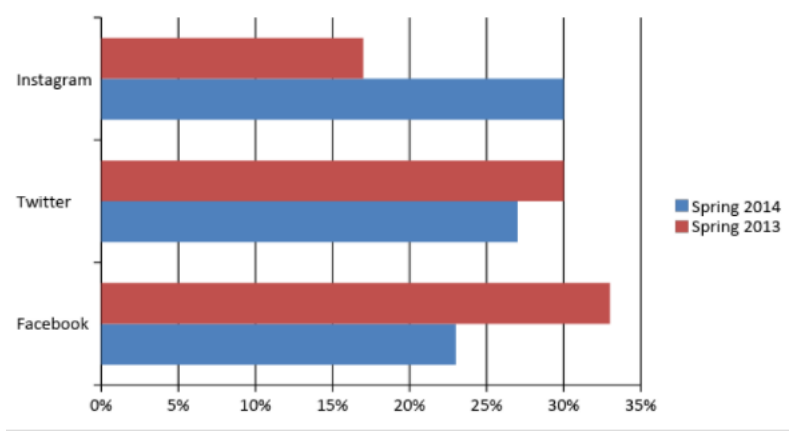


Dari tahun ke tahun, Instagram juga semakin banyak digunakan oleh orang lain untuk berkomunikasi dan berbagi cerita. Sejak itu, jumlah anggota di Instagram telah tumbuh secara eksponensial sekitar 700 juta pengguna yang terdaftar pada tahun 2017 (Dogtiev, 2018).

Pertumbuhan angka pengguna instagram ini karena mempunyai keunikan tersendiri dibandingkan dengan sosial media lainnya yaitu menerapkan strategi berbasis visual sehingga dapat dikatakan bahwa pemasaran yang dilakukan pada Instagram adalah cara efektif untuk mengiklankan produk karena gambar dapat mengekspresikan ribuan kata dan juga dapat menarik orang yang melihatnya. Instagram yang dienuhi dengan konten visual ini dapat memungkinkan perusahaan untuk menciptakan strategi pemasaran yang baru dan tidak hanya untuk mempublikasikan foto dan video, tetapi juga untuk memperhatikan apa yang dilakukan konsumen dengan produk dari perusahaan, apakah mereka mengapresiasi konten dengan menyukai atau dikomentari (Nuryadin et al., 2020).

Perkembangan Instagram dari tahun ke tahun juga menyebabkan bertambahnya beberapa fitur di Instagram seperti memposting foto atau video, cerita kehidupan, live streaming, berbagi informasi, mengikuti orang lain, dan diikuti orang lain. Terdapat dua fitur utama Instagram yaitu mengunggah foto atau video dan Instagram Stories yang memiliki konsep berbagi aktivitas sehari-hari dengan mengirim foto dan video yang hilang secara otomatis setelah 24 jam (sholeh \& rusdi, 2019). Selain itu, Instagram memfasilitasi penggunanya untuk mengedit dan mengunggah foto dan video kemudian menerima komentar dan "like" dari orang lain, mengikuti profil orang lain, diikuti oleh orang lain, serta siaran langsung.

Bertambahnya pengguna dan fitur Instagram ini memiliki keuntungan tersendiri bagi industry pariwisata khususnya perhotelan sebagai media pemasarannya karena Instagram lebih sering digunakan daripada media sosial yang lain. Instagram memiliki kelebihan tingkat keterlibatan pengguna yang tinggi daripada Facebook dan Twitter, terdapat 93\% brand bisnis mempunyai akun instagram untuk strategi pemasarannya, karena dalam Instagram bisa menghubungkan perusahaan dengan konsumenya (Varma, Dhakane, \& Pawar, 2020). Pada Gambar 2.1 dijelaskan tentang minat utama pada Instagram

\section{Gambar 4. Persentase Minat Utama Pada Instagram}

Minat utama yang dikejar orang adalah perjalanan $(45 \%)$, musik $(44 \%)$ dan makanan dan minuman (43\%), dan minat lainnya. Pemasar memiliki peluang untuk terhubung dengan konsumen mereka dengan menggunakan Instagram. Hal ini dapat

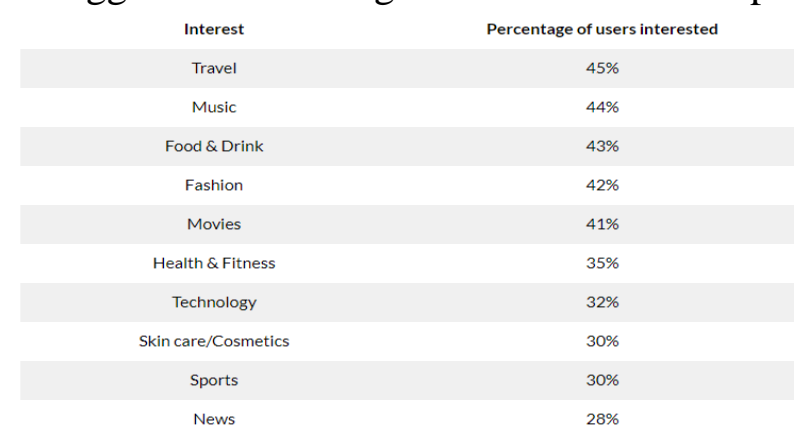
membantu menjaga konten mereka tetap relevan dan memberikan informasi tentang minat konsumen. Dijelaskan beberapa tindakan yang dilakukan oleh pengguna Instagram saat mereka melihat postingan tertentu pada gambar dibawah ini.

\section{Gambar 5. Persentase Tindakan Yang Dilakukan Pengguna Instagram}

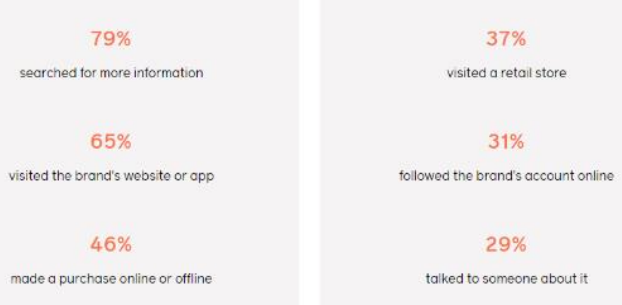

Dari gambar tersebut bisa diketahui bahwa mereka mengambil tindakan setelah melihat informasi produk di Instagram, seperti mengikuti suatu merek, mengunjungi situs web mereka, atau melakukan pembelian secara online. Instagram telah mempermudah tindakan tersebut bagi konsumen dengan penambahan 
fitur Shopping di Instagram, sehingga orang dapat mengklik produk tertentu.

\section{Penelitian Terdahulu}

Penelitian yang dilakukan ini tidak lepas dari referensi penelitian sebelumnya mengenai pemasaran sosial media di industry perhotelan. Table 2.1 ini menjelaskan beberapa penelitian terdahulu yang mempunyai keterkaitan antara pemasaran sosial media dengan industri perhotelan.

Penelitian Terdahulu

Sumber: Modifikasi penulis dari beberapa literature, 2021

Berdasarkan table 2.1 Penelitian

Terdahulu dapat dilihat bahwa penelitian ini memiliki persamaan pada variabel yang diambil yaitu meneliti media sosial sebagai media pemasaran di industry perhotelan. Penelitian Hsien-Cheng Lin et al., (2020) yang berjudul "Task-Technology Fit Analysis of Social Media Use for Marketing in The Tourism and Hospitality Industry : A Systematic Literature Review" menjadi referensi penulis dalam penelitian ini yang menekankan pada faktor yang mendasari industri pariwisata menjadikan Instagram sebagai media pemasarannya.

Perbedaan penelitian ini dengan penelitian terdahulu dapat dilihat dari media pemasaran yang digunakan. Pada penelitian terdahulu peneliti meneliti media sosial secara umum, namun kali ini penulis menggunakan media sosial Instagram sebagai media pemasaran pada industri perhotelan.

\section{Kerangka Pemikiran}

Pariwisata semakin memperkuat aktivitasnya baik di bidang ekonomi maupun sosial, hal ini dibuktikan dengan meningkatnya permintaan pariwisata di seluruh dunia sehingga pihak industry pariwisata ini berlomba-loma memberikan produk dan pelayanan terbaik untuk pelanggannya. Mengingat kenyataan ini dan premis dasar yang disebutkan di atas, bisnis pariwisata juga telah memilih serangkaian opsi strategis baru yang menjamin daya saing mereka dalam hal baru di lingkungan internasional (Gustavo et al., 2013)
Selama 25 tahun terakhir, persaingan di industry pariwisata khususnya perhotelan lebih besar, lebih banyak merek, dan keragaman produk hotel yang lebih besar. Disisi lain, kejadian ini mempunyai akibat yang positif untuk konsumen karena mereka memiliki lebih banyak produk hotel untuk dipilih dan kemampuan untuk mempengaruhi harga yang diminta hotel, tetapi berbalik dengan pihak hotel yang semakin sulit mendorong dan membujuk calon tamu untuk menginap di hotelnya, namun pelaku bisnis perhotelan saat ini memiliki alat untuk membantu dalam upaya pemasaran hotel dan untuk meningkatkan potensi kesuksesan pemasaran hotel. Potensi pemasaran hotel saat ini berkaitan erat dengan penggunaan teknologi digital, seperti termasuk web, media sosial, dan blog yang menawarkan pemahaman langsung dari kebutuhan pelanggannya, keinginan, dan keterjangkauan yang cukup luas bukan yang diperoleh melalui pihak ketiga (Jayawardena, 2013).

Penggunaan teknologi digital juga tidak hanya memungkinkan untuk mengetahui keinginan dan kebutuhan konsumen, tetapi mereka juga memfasilitasi pemberdayaan konsumen dan umpan balik konsumen untuk mendapatkan informasi sehingga bisa saling berkomunikasi antara industry dengan konsumennya. Dengan adanya teknologi digital dalam komunikasi pemasaran, maka informasi yang diperoleh dari database pelanggan akan didapatkan dengan mudah, penyampaian informasi lebih jelas, dapat memelihara hubungan jangka panjang dengan konsumen dan stakeholder dan menciptakan serta memelihara ekuitas merek (Šeric et al., 2015)

Komunikasi pemasaran saat ini juga semakin meningkat dengan adanya teknologi baru karena dapat menjangkau pelanggan secara luas dan pelanggan dapat berinteraksi langsung dengan perusahaan. Teknologi baru telah mendorong perusahaan untuk beralih kepada komunikasi masa agar jangkauannya lebih luas dan terjadi komunikasi dua arah sehingga pelannggan juga dapat memainkan peran yang jauh lebih partisipatif proses pemasaran. (Kotler and Keller, 2016) 
Seiring berjalannya waktu, teknologi dan informasi semakin berkembang terutama pada penggunaan media sosial yang bisa memberikan fasilitas komunikasi jarak jauh kepada para penggunanya. Perkembangan media sosial ini telah diakui secara luas bahwa media sosial memfasilitasi dan meningkatkan komunikasi tidak hanya bagi penggunanya saja tetapi juga antara bisnis dan pelanggan (Aladwani, \& Dwivedi, 2018). Media sosial ini dapat digunakan oleh pemasar agar selalu terhubung dengan konsumennya. Dengan adanya pemasaran melalui media sosial ini sangat berbeda dengan pemasaran bahkan 10 tahun yang lalu, dengan perilaku pemasaran baru, peluang, dan tantangan yang muncul, oleh karena itu pemasar juga harus mengerti pada tiga kekuatan transformatif dalam manajemen pemasaran yaitu teknologi, globalisasi, dan tanggung jawab sosial (Kotler \& Keller, 2016). Munculnya teknologi media sosial menguntungkan hotel dalam mempromosikan produk dan pelayanan dalam ruang lingkup.

lokal dan internasional karena melalui platform sosial media, wisatawan dapat mengumpulkan informasi tentang tujuan perjalanan atau akomodasi. Selain menguntungkan wisatawan, teknologi media sosial membantu hotel untuk berkomunikasi dengan pelanggannya dan hotel dapat memahami kebutuhan pelanggan mereka dan bersaing dengan pesaing mereka dengan lebih baik tetapi jika tidak dikelola secara efektif akan berdampak negatif dari platform online ini (Hashim et al., 2017)

Oleh karena itu, pemasaran media sosial memainkan peran yang semakin penting karena sebagian besar pemasar menyadari bahwa hanya mengandalkan media pemasaran tradisional tidaklah tepat efektif lebih lama. Terdapat satu temuan yang menunjukkan bahwa manfaat utama menggunakan jaringan media sosial adalah meningkatkan pengenalan merek, dan dapat berbagi informasi dengan wisatawan di sekitar dunia melalui media sosial mengingat layanan hotel, sering kali tidak diketahui kualitasya sebelum dikonsumsi sehingga sebagian besar konsumen bergantung pada sosial media untuk menyimpulkan kualitas barang dan jasa (Wirtz dan Chew, 2002). (Kim. 2017)

Social Media Marketing ini berkaitan dengan industri pariwisata dan perhotelan untuk meningkatkan komunikasinya dengan konsumen. Iklan Instagram adalah bagaimana perusahaan terhubung dengan Instagram dan memasarkan penawaran mereka kepada audiens target mereka. Baru-baru ini, merek mendapatkan popularitas sebagai cara inovatif untuk memamerkan budaya mereka, merekrut staf baru, terlibat dengan konsumen, dan melihat barang dari sudut pandang baru. Menariknya, pengikut Instagram lebih aktif daripada pengguna media sosial biasa. Dan sementara tren tampaknya menunjukkan penurunan keterlibatan Instagram, situs tersebut masih memberikan tingkat keterlibatan bisnis yang lebih tinggi dibandingkan dengan Twitter dan Facebook. Namun pengguna lebih dari sekadar aktif di Instagram - mereka juga sering kali menjadi pembeli online (Miller, 2020).

Saat ini, beberapa perusahaan menggunakan media sosial sebagai sarana promosi merek, seperti Facebook, Twitter, bahkan Instagram namun hal yang membedakan Instagram dengan media sosial lainnya adalah Instagram menerapkan strategi berbasis visual. Segala sesuatu tentang Instagram adalah tentang foto sehingga dapat mempromosikan produk dengan cara yang baru dan lebih menarik, selain itu sosial media juga dapat melihat aktivitas konsumen dengan produk mereka (Nuryadin et al., 2020).

Fitur interaktif platform media sosial seperti Instagram ini dapat memberikan lebih banyak informasi pelanggan dan akses langsung ke pelanggan secara efektif dan bisa mendapa umpan balik yang sangat penting untuk mengembangkan layanan dan produk baru. Sosial media merupakan saluran langsung antara pelanggan dan hotel untuk memberikan informasi terkini tentang hotel secara langsung dan interaktif dengan pelanggan dengan cara yang cepat dan murah, secara instan dan murah sehingga pengguna Instagram semakin meningkat setiap harinya (Undey et al., 2019) 
Semakin

meningkatnya penggunaan sosial media dalam pemasaran industry pariwisata dan perhotelan ini pasti mempunyai dampak baik bagi industry ataupun bagi konsumennya. Oleh karena itu peneliti membuat kerangka pemikiran penelitian ini pada bagan yang digambarkan dalam gambar 2.1. Menurut (Adom, 2018) kerangka pemikiran ini menjelaskan jalur penelitian dan mendasarinya dengan kuat dalam konstruksi teoritis. Tujuan keseluruhan dari dua kerangka kerja ini adalah untuk membuat temuan penelitian lebih bermakna, dapat diterima oleh konstruksi teoritis di bidang penelitian dan memastikan generalisasi.

\section{Gambar 6. Kerangka Pemikiran}

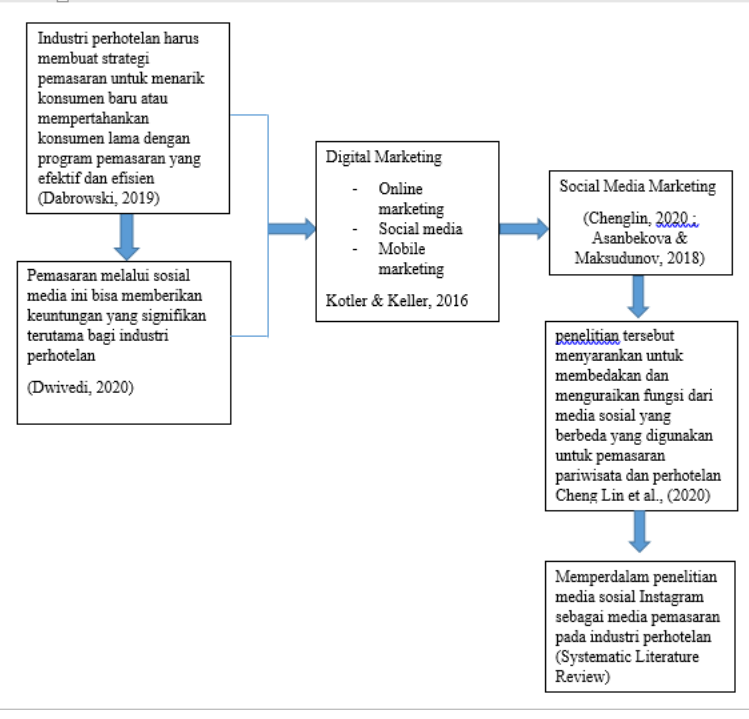

\section{METODE PENELITIAN}

Dalam penelitian ini, metode yang digunakan adalah systematic literature review. Systematic Literature Review merupakan tinjauan pencarian yang komprehensif untuk menemukan teori yang relevan tentang topik tertentu, kemudian diidentifikasi, dinilai, dan disintesis menurut metode eksplisit yang telah ditentukan sebelumnya sehingga pendekatan SLR memberikan kejelasan, transparansi dan ketidakberpihakan serta cakupan yang inklusif di wilayah tertentu.

Adapun tujuan dari systematic literature review ini yaitu agar mensintesis literatur dan menciptakan suatu argumen yang kredibel mengenai pertanyaan yang ada dalam penelitian tersebut. Tujuan systematic literature review ini diantaranya adalah untuk mensintesis literatur, menciptakan argumen yang mengarah pada pertanyaan penelitian bukan sekadar ringkasan literatur, selain itu argumen yang tercipta juga berguna untuk membenarkan tujuan dan membangun kredibilitas penelitian tersebut (Berdanier \& Lenart, 2021).

Pendekatan systematic literature review akan menghasilkan penelitian kualitatif kredibel dikarenakan menetapkan topik yang jelas, tujuan dan pertanyaan penelitian yang jelas, cara mencari sumber tinjauan pustaka yang jelas, dan juga mensintesis literature tersebut sebelum ditarik kesimpulannya. Terdapat enam langkah utama dalam mengembangkan dan melakukan systematic literature review (Efron \& Ravid, 2019 ; Suswanto, 2010), berikut tahapannya:

1. Memformulasikan pertanyaan penelitian (formulating the review question).

2. Melakukan pencarian literatur systematic review (conducting a systematic literature search).

3. Melakukan skrining dan seleksi artikel penelitian yang cocok (screening and selecting appropriate research articles).

4. Melakukan analisis dan sintesis temuan-temuan kualitatif (analyzing and synthesizing qualitative findings).

5. Memberlakukan kendali mutu (maintaining quality control).

6. Menyusun laporan akhir (findings).

\section{Perencanaan Penelitian}

Social media marketing pada Instagram ini berpengaruh terhadap industri pariwisata khususnya di industri perhotelan karena instagram lebih sering digunakan dan mempunyai pengguna aktif yang lebih banyak daripada sosial media lain yang bisa dimanfaatkan untuk strategi pemasaran dan juga bisa menghubungkan industri dengan konsumennya (Varma et al, 2020). Oleh karena itu, penting bagi penyedia layanan pariwisata untuk melakukan upaya pemasaran pada sosial 
media karena telah terbukti lebih efektif daripada pemasaran tradisional, pemasaran media sosial juga memungkinkan komunikasi dua arah antara konsumen dan industri sehingga membantu perusahaan membangun hubungan dan loyalitas konsumen jangka panjang, mendukung promosi produk dan layanan baru secara real-time, dan menghasilkan data konsumen yang dapat dimanfaatkan untuk menargetkan, melibatkan, dan menumbuhkan customer base (Pappeti et al., 2018).

Hal yang harus dilanjutkan setelah fokus penelitian ditentukan adalah memformulasikan review question karena Review question merupakan bagian yang penting dari penelitian systematic literature review. Review question ini digunakan sebagai acuan dalam proses pencarian dan ekstraksi literatur. Jawaban dari review question yang telah tentukan pada awal penelitian merupakan hasil dari analisis dan sintesis data. Review question yang baik adalah yang bermanfaat, terukur, arahnya ke pemahaman terhadap stateof-the-art research dari suatu topik penelitian. Untuk membantu memfokuskan penelitian dan memperjelasnya maka peneliti menggunakan pendekatan PICo.

Setelah membuat tujuan dan cakupan yang jelas pada review question, selanjutnya adalah merumuskan research question, Peneliti akan membahas mengenai:

1. Mengapa Instagram digunakan sebagai media pemasaran di indusri perhotelan?

2. Dalam konsep social media marketing apa yang banyak diteliti pada jurnal sebelumnya terkait penerapan Instagram di Industri perhotelan?

\section{Teknik Pengumpulan Data}

Teknik pengumpulan data ini merupakan tahap dalam mengumpulkan data-data yang dibutuhkan untuk menjawab rumusan masalah penelitian. Sesuai dengan jurnal yang diteliti oleh Triandini, menyebutkan bahwa teknik pengumpukan data adalah tahap di mana datadata untuk penelitian dikumpulkan (Triandini et al., 2019). Dalam penelitian ini, teknik yang akan digunakan oleh penulis adalah Studi literature. Dimana studi literature ini adalah teknik pengumpulan data dengan cara mempelajari dan menganalisis buku, jurnal, makalah, dan homepage/website guna memperoleh informasi yang bisa menjawab rumusan masalah penelitian dan konsep-konsep yang berkaitan dengan variabel penelitian ini yaitu social media marketing. Agar teknik pengumpulan data dalam penelitian ini lebih difahami dengan jelas, peneliti mengumpulkan dan menyajikannya dalam tabel berikut ini:

Pada proses pengumpulan literatur yang akan digunakan untuk menjawab research question dibutuhkan juga database untuk menampung jurnal yang berkaitan dengan variabel penelitian serta mempunyai kredibelitas yang tinggi. Database yang digunakan peneliti adalah Google schoolar, sciencedirect, emerald dan sage dalam mengumpulkan jurnal. Peneliti juga mendapatkan beberapa jurnal melalui springerlink, proquest, dan google scholar.

Sebelum melakukan pencarian ke dalam database yang sudah disebutkan, terlebih dahulu peneliti menentukan keywords yang akan digunakan dalam pencarian. Pemilihan keywords ini berdasarkan pada research question untuk mendapatkan hasil yang akurat dalam pencarian di database. Keywords yang peneliti gunakan sebagai berikut.

Research question 1: Mengapa Instagram digunakan sebagai media pemasaran di indusri perhotelan?

Tabel 1. Keywords Research Question 1

\begin{tabular}{|l|l|}
\hline Construct & $\begin{array}{l}\text { Keywords } \\
\text { synonyms }\end{array}$ \\
\hline Use & $\begin{array}{l}\text { User, usage, } \\
\text { application, } \\
\text { implementation }\end{array}$ \\
\hline Instagram & $\begin{array}{l}\text { Instagram marketing, } \\
\text { sociar media } \\
\text { marketing instagram, } \\
\text { social media } \\
\text { marketing, Instagram } \\
\text { marketing for hotel }\end{array}$ \\
\hline Hotel & $\begin{array}{l}\text { Hotel, Hotel Industry, } \\
\text { Hospitality Industry, } \\
\text { accommodation, } \\
\text { lodging }\end{array}$ \\
\hline
\end{tabular}


Tabel 2. Keywords Research Question 2

\begin{tabular}{|l|l|}
\hline Construct & Keywords - synoym \\
\hline Instagram & $\begin{array}{l}\text { Instagram marketing, social } \\
\text { media marketing, social media } \\
\text { marketing in hotel, Instagram } \\
\text { marketing for hotel }\end{array}$ \\
\hline Hotel & $\begin{array}{l}\text { Hotel, Hotel Industry, } \\
\text { Hospitality Industry, } \\
\text { accommodation, lodging }\end{array}$ \\
\hline
\end{tabular}

Keywords yang digunakan untuk mencari topik penelitian dalam database ini terdiri dari kata-kata yang telah direncanakan oleh penulis. Kosakata yang direncanakan oleh penulis ini akan mengidentifikasi topik utama pada artikel atau jurnal sehingga bisa membantu peneliti untuk tetap melakukan pencarian sesuai dengan rencanya yang diatur dan membantu untuk membentuk search strings yang nantinya akan diaplikasikan kedalam database.

Agar bisa membentuk search string maka peneliti menggunakan boolean operators AND/OR/NOT untuk memperbaiki hasil pencarian. Berikut ini dijelaskan mengenai search string yang digunakan oleh peneliti.

Lalu, search string tersebut diaplikasikan pada database dan diatur menggunakan tools referensi Zotero. Peneliti juga menggunakan beberapa keywords agar bisa menghasilkan pencarian sesuai denan fokus penelitian dan dapat menjawab research question.

Setelah mengaplikasikan search string pada beberapa database, maka akan didapatkan total jumlah jurnal. Selanjutnya akan memasuki tahap deduplikasi dan tittle and abstract screening menggunakan software Zotero sehingga akan mendapatkan jurnal yang valid. Selanjutnya jurnal tersebut diolah melalui full text screening dengan beberapa kriteria sebagai berikut:
Tabel 3. Kriteria Full Text Screening

\begin{tabular}{|l|l|}
\hline Inclusion criteria & Exclusion criteria \\
\hline $\begin{array}{l}\text { Di publish antara tahun } \\
\text { 2010-2021 }\end{array}$ & $\begin{array}{l}\text { Diluar waktu yang } \\
\text { ditentukan }\end{array}$ \\
\hline $\begin{array}{l}\text { Literatur ditulis dalam } \\
\text { bahasa inggris }\end{array}$ & $\begin{array}{l}\text { Literatur tidak } \\
\text { menggunakan } \\
\text { bahasa inggris }\end{array}$ \\
\hline $\begin{array}{l}\text { Dalam konteks social } \\
\text { media marketing } \\
\text { Instagram di hotel }\end{array}$ \\
\hline \multicolumn{2}{|c|}{ Setelah mendapatkan jurnal } \\
\hline
\end{tabular}

berdasarkan kriteria tersebut, selanjutnya akan dijadikan final papper dan dianalisis. Kemudian peneliti melakukan ekstraksi data menggunakan template analysis, sesuai dengan pendapat King dalam jurnal Burton\&Galvin menyebutkan bahwa bahwa peneliti membuat daftar literatur yang relevan dengan pertanyaan penelitian kemudian terus di analisis sampai mendapatkan suatu temuan tertentu dalam penelitian kualitatif (Burton \& Galvin, 2018). Dalam penelitian ini menggunakan basic data extraction template (stebbin-boaz, 1999) untuk mendapatkan data yang spesifik dan relevan dari jurnal tersebut.

\section{Rancangan Analis Data}

Mengumpulkan jurnal penelitian yang sesuai dengan topik penelitian, kemudian dibuat kesimpulan jurnal meliputi nama peneliti, tahun terbit jurnal, rancangan studi, tujuan penelitian, dan ringkasan hasil penelitian atau temuan. Kemudian, ringkasan jurnal penelitian ini dimasukan dan diurutkan ke dalam tabel. Jurnal dibaca dan dicermati secara keseluruhan untuk lebih memperjelas analisis abstrak. Ringkasan jurnal tersebut kemudian dilakukan analisis terhadap isi yang terdapat dalam tujuan penelitian dan hasil/temuan penelitian. Metode analisis yang digunakan menggunakan analisis isi jurnal. Setelah itu, peneliti menganalisis kesamaan dan perbedaan yang ada pada studi atau jurnal tersebut. Berikut analisis data yang terdapat 3 tahap (Jesson et al., 2011):

Melakukan analisis jurnal yaitu menuliskan kesimpulan penting yang akan 
membangun bukti dan menjelaskan topik penelitian dalam final paper.

Membandingkan final papper untuk mengetahui persaman dan perbedaannya agar mendapatkan data yang komparatif.

Membuat catatan tentang kelebihan dan kekurangan setiap jurnal dan celah untuk penelitian selanjutnya, namun harus tetap focus terhadap research question agar bisa menuliskan review yang relevan.

Rancangan Sintesis Data

Tujuan dari penelitian ini adalah untuk menganalisis studi yang sudah ada kemudian memberikan gambaran baru yang disajikan dalam temuan ini, semua literatur yang lolos penilaian kualitas kemudian diekstraksi datanya untuk dinilai kelengkapan data guna menguji keakuratan pencatatan informasi yang terdapat dalam penelitian ini, kemudian data dari setiap studi yang disintesis, dikategorikan dan kemudian disimpan dalam spreadsheet.

Sintesis data ini merupakan cara untuk menghubungkan setiap bagian dalam ekstraksi dan dengan melakukan proses sintesis data, maka tujuan penelitian dari penelitian ini akan tercapai . Hasil analisis penilaian kualitas dan sintesis data dari penelitian tersebut harus menjawab knowledge gap dan cakupan penelitian, setelah itu hasil dari semua temuan dalam penelitian ini harus diberitahukan dan memberi catatan limitasi metode dan teori pada penelitian yang telah dilakukan ini

\section{HASIL DAN PEMBAHASAN}

\section{Hasil}

Penelitian ini menghasilkan total 6 final paper yang nantinya akan diidentifikasi oleh peneliti untuk menjawab research question. Penelitian tersebut sebagian besar bersifat kuantatif. Berikut literatur yang penulis dapatkan setelah melalui tahapan systematic literature review funnel.
Tabel 4. Final Papper

\begin{tabular}{|l|l|l|l|}
\hline No & Judul & Author & Tahun \\
\hline 1 & $\begin{array}{l}\text { Lifestyle Experiences: Exploring } \\
\text { Key Attributes of Lifestyle Hotels } \\
\text { Using Instagram User-Created } \\
\text { Contents in South Korea }\end{array}$ & $\begin{array}{l}\text { Yoojin Han and } \\
\text { Hyunsoo Lee }\end{array}$ & 2021 \\
\hline 2 & $\begin{array}{l}\text { Social Media Marketing in } \\
\text { Selected UK Luxury Hotels }\end{array}$ & $\begin{array}{l}\text { Mandy Claudia } \\
\text { Leue, } \\
\text { Timothy Jung, and } \\
\text { Tim Knowles }\end{array}$ & 2012 \\
\hline 3 & $\begin{array}{l}\text { The Marketing Power of } \\
\text { Instagram: A Content Analysis of } \\
\text { Top Hotel Enterprises in } \\
\text { Kyrgyzstan }\end{array}$ & $\begin{array}{l}\text { Meerim } \\
\text { Asanbekova dan } \\
\text { Azamat } \\
\text { Maksudunov }\end{array}$ & 2018 \\
\hline 4 & $\begin{array}{l}\text { Engaging with Customer Using } \\
\text { Social Media Platform: A Case } \\
\text { Study of Malaysia Hotels }\end{array}$ & $\begin{array}{l}\text { Kamarul Faizal } \\
\text { Hashim, Nawar } \\
\text { Abbood Fadhil }\end{array}$ & 2017 \\
\hline 5 & $\begin{array}{l}\text { Instagram Usage In Hospitality } \\
\text { Sector As A Social Media } \\
\text { Marketing Strategy }\end{array}$ & $\begin{array}{l}\text { Nur Undey, Ibrahim } \\
\text { Koroglu, Erol Duran }\end{array}$ & 2019 \\
\hline 6 & $\begin{array}{l}\text { Challenges of social media } \\
\text { marketing- } \\
\text { an explorative international } \\
\text { study of hotels }\end{array}$ & Karin Högberg & 2017 \\
\hline
\end{tabular}

Hasil pencarian dari 5 database menunjukan bahwa banyak penelitian terkait Instagram sebagai social media marketing di industry perhotelan diantara tahun 2011 -2021 yang menunjukan bahwa instagram masih banyak diteliti hingga saat ini. Namun masih jarang penelitian terkait instagram di industry perhotelan menggunakan metode Systematic Literature Review. Selanjutnya peneliti melihat jurnal tersebut berdasarkan tahun penelitian untuk mengetahui fokus penelitian Instagram di industry perhotelan paling banyak pada tahun berapa.

\section{Tabel 5. Database Artikel}

\begin{tabular}{ll}
\hline Database & Jumlah \\
\hline Google Schoolar & 3 \\
\hline Science Direct & 1 \\
\hline Elsevier & 2 \\
\hline
\end{tabular}

Artikel terkait instagram di industry perhotelan tersebar di banyak publikasi atau database. Peneliti berfokus pada artikel yang khusus membahas Instagram di industry perhotelan. Setelah melalui berbagai tahapan dalam systematic literature review dan mendapatkan literatur yang nantinya akan menjawab research question peneliti. Selanjutnya dilakukan ekstraksi data menggunakan basic data extraction template. Peneliti menggunakan basic data extraction template dari (Hayden, Boaz, \& Bernard, 1999) untuk mendapatkan data spesifik dari 6 artikel tersebut. 
Pembahasan

(Han,

penelitian

2021)

menemukan

bahwa mengenai Instagram menggambarkan gambar hotel, berisi lebih banyak pengalaman dalam ruangan, sebagian besar ditampilkan kamar tamu dan fasilitas hotel. Selain itu, para tamu menggunakan tagar yang berhubungan dengan harian hidup, tidak hanya tentang bepergian, dalam gambargambar itu. Oleh karena itu, konsumsi dalam gaya hidup hotel tidak harus dipahami dalam konteks akomodasi, melainkan dari perspektifdari aktivitas yang sedang berlangsung. Seperti penelitian sebelumnya yang menggarisbawahi gagasan bahwa kegiatannya beragam dan pengalaman yang diciptakan oleh tamu hotel sangat penting untuk hotel di masa depan.

(Claudia et al., 2012) Membahas media sosial hotel bintang empat dan lima di Inggris semakin banyak membuat strategi pemasaran sosial media agar tetap terhubung dengan target pasar yang ada dan menarik pelanggan baru. Hotel di Inggris memiliki fokus pada sosial media mereka untuk meningkatkan jumlah pengikut dan menjadi viral; tamu hotel akan menyebabkan word-of-mouth dari pengalaman mereka. Konsumen juga ingin minimalisasi risiko dalam proses pembelian sehingga menggunakan sosial media. Selanjutnya, penelitian ini mengungkapkan bahwa adopsi media sosial dalam hotel di Inggris tampaknya telah berevolusi dari studi sebelumnya, meskipun tingkat adopsi media sosial bervariasi antara hotel namun pihak hotel menyadari peluang untuk memanfaatkan sosial media.

(Asanbekova et al., 2018) menunjukan bahwa Media sosial sangat penting bagi hotel untuk mempromosikan layanan, berinteraksi, dan berkomunikasi dengan pelanggan yang ada dan calon pelanggan, bertukar informasi, memahami kebutuhan dan keinginan pelanggan. Pengguna sebelum memilih hotel terlebih dahulu mengunjungi halaman media sosial dan mengevaluasi layanan mereka. Dalam hal ini, posting dalam format gambar berdampak besar pada pelanggan keputusan. Namun, ini bukanlah kekuatan pemasaran
Instagram sepenuhnya. Jurnal ini menunjukan bahwa Media sosial sangat penting bagi hotel untuk mempromosikan layanan, berinteraksi, dan berkomunikasi dengan pelanggan yang ada dan calon pelanggan, bertukar informasi, memahami kebutuhan dan keinginan pelanggan. Pengguna sebelum memilih hotel terlebih dahulu mengunjungi halaman media sosial dan mengevaluasi layanan mereka. Dalam hal ini, posting dalam format gambar berdampak besar pada pelanggan keputusan. Namun, ini bukanlah kekuatan pemasaran Instagram sepenuhnya.

(Hashim et al., 2017) menjelaskan bahwa Operator hotel di Malaysia tidak begitu memanfaatkan potensi sosial media untuk berinteraksi dengan konsumen. Berdasarkan temuan penelitian, operator hotel mempunyai keterbatasan pemahaman tindakan untuk melakukan pemasaran sosial media. Namun, mereka mencoba untuk memahami bagaimana memanfaatkan sosial media untuk membantu meningkatkan hubungan dengan konsumen di hotel Malaysia. Namun, untuk meningkatkan keterlibatan pelanggan menggunakan sosial media, mereka harus memberi perhatian terhadap 5 dimensi yaitu awareness, attitude expression, voicing opinion, advocancy, dan loyalty. Sementara itu, berfokus untuk mengetahui kegunaan sosial akan membantu hotel untuk berinteraksi dengan konsumen yang lebih akurat.

(Undey et al., 2019) menjelaskan bahwa harus menggunakan strategi pemasaran di instagram secara efektif. Seperti merencanakan konten secara sering dan konsisten. Selain itu, hashtag juga harus digunakan secara efektif karena memiliki banyak berpengaruh pada tingkat interaksi konten dan agar mencapai audiens yang ditargetkan. Berbagi pengalaman pelanggan tentang hotel juga penting di pemasaran Instagram karena calon pelanggan tidak dapat mencoba hotel sebelum membeli layanan tersebut sehingga pengalaman pelanggan lain memainkan peran penting dalam perilaku pembelian. Platform Instagram Stories adalah hal yang paling penting untuk memastikan bahwa hotel berada di puncak 
umpan pengikut Anda. Instastory dapat menarik pengikut baru untuk berkunjung ke profil Instagram perusahaan dan meningkatkan tingkat interaksi. Selain itu, pemasaran di Instagram menggunakan influencer adalah pilihan karier yang populer dan efektif. Pemasaran influencer adalah strategi terkuat dalam pemasaran instagram yang memungkinkan perusahaan untuk menjangkau komunitas tertentu bahkan di target audiens yang sulit dijangkau. Dialog aktif yang diberikan oleh instagram dapat meningkatkan manajemen informasi pelanggan untuk lebih memahami keinginan dan kebutuhan pelanggan, sehingga Instagram menjadi salah satu alat yang digunakan secara aktif untuk melakukan perubahan pada produk yang sudah ada atau memfasilitasi pengembangan produk.

(Högberg, 2017) Secara umum, hotel yang diteliti banyak memfokuskan aktivitas sosial media marketing mereka di Facebook dan Instagram. Penggunaan sosial media marketing di beberapa negara Eropa cukup mendasar dan langkah pertama dari proses implementasinya adalah hadir di saluran sosial media daripada menciptakan interaksi. Studi ini menunjukkan bahwa hotel belum sepenuhnya menyesuaikan strategi pemasaran mereka agar sesuai dengan saluran sosial media. Banyak hotel mengandalkan pengetahuan individu tentang dan pengalaman dengan Sosial media. Namun, pengalaman mereka sering didasarkan pada penggunaan pribadi oleh karena itu mungkin tidak cocok untuk sosial media marketing. Sejak perkembangan sosial media yg pesat, dapat dikatakan bahwa pemasar di hotel dipaksa untuk belajar sambil melakukan pemasaran sosial media sehingga menciptakan dilema dengan struktur organisasi jaringan hotel. Hasil wawancara juga mengungkapkan bahwa ada kekhawatiran dari hotel tentang kehilangan kontrol merek dan konten pemasaran mereka saat menggunakan sosial media. Namun, mereka juga mencoba melihat apa yang berhasil dan apa yang tidak berhasil dalam interaksi dengan pelanggan, tetapi juga melihat penggunaan sosial media pesaing yang dapat dilihat sebagai langkah awal dalam proses pembelajaran. Banyak hotel menggunakan
Instagram, dan sebagian besar hotel memiliki akun Twitter.

\section{PENUTUP \\ Kesimpulan}

Dari penjelasan diatas maka bisa ditarik kesimpulan bahwa hotel menggunakan sosial media Instagram sebagai pemasarannya karena Instagram memiliki banyak fitur seperti hashtag dan instastory yang dapat menjangkau audiens secara luas. Selain itu, postingan dalam format gambar juga berdampak besar pada keputusan pelanggan. Namun, ini bukanlah kekuatan pemasaran Instagram sepenuhnya.

Disisi lain, penelitian yang sering dilakukan sebelumnya adalah mengenai penerapan sosial media marketing di hotel. Hasilnya adalah tidak semua hotel mengerti dan menggunakan sosial media sepenuhnya untuk melakukan pemasaran, namun mereka tetap menggunakan media sosial untuk kesadaran merek menggunakan beberapa platform tidak hanya Instagram, namun bisa juga twitter, facebook, linkedin, youtube, dan lain sebagainya.

\section{Saran}

Dalam penelitian ini masih banyak kekurangan yang dapat diperbaiki dengan adanya penelitian selanjutnya. Untuk saran penelitian selanjutnya adalah meneliti lebih jauh tentang sosial media marketing di Instagran karena peneliti hanya menggunakan sebagian database untuk melakukan pencarian jurnal

\section{DAFTAR PUSTAKA}

[1] Adeyinka-ojo, S., Lee, S., \& Teo, J. (2019). Hospitality and tourism education in an emerging digital economy education. 12(2), 113-125. https://doi.org/10.1108/WHATT-12-20190075

[2] Ajina, A. S. (2019). The perceived value of social media marketing: An empirical study of online word of mouth in Saudi Arabian context. Entrepreneurship and Sustainability Issues, 6(3), 1512-1527. https://doi.org/10.9770/jesi.2019.6.3(32) 
[3] Alansari, M. T., Velikova, N., \& Jai, T. M. (Catherine). (2018). Marketing effectiveness of hotel Twitter accounts: the case of Saudi Arabia. Journal of Hospitality and Tourism Technology, 9(1), 63-77. https://doi.org/10.1108/JHTT-092017-0096

[4] Amelia, Rizka; Hidayatullah, S. (2020). The Effect of Instagram Engagement to Purchase Intention and Consumers , Luxury Value Perception as the mediator in the Skylounge Restaurant. 5(4), 958-966.

[5] Arat, T. (2017). the Role of Social Media in Tourism. December. https://doi.org/10.20472/iac.2016.025.006

[6] Arrigo, E. (2018). Social media marketing in luxury brands: A systematic literature review and implications for management research. Management Research Review, 41(6), 657-679. https://doi.org/10.1108/MRR-04-20170134

[7] Authors, F. (2017). Determinants of hotel social media continued usage Article information :

[8] Burton, N., \& Galvin, P. (2019). Using template and matrix analysis: A case study of management and organisation history research. Qualitative Research in Organizations and Management: An International Journal, 14(4), 393-409. https://doi.org/10.1108/QROM-04-20181626

[9] Chu, S. C., Deng, T., \& Cheng, H. (2020). The role of social media advertising in hospitality, tourism and travel: a literature review and research agenda. International Journal of Contemporary Hospitality Management, 32(11), 3419-3438. https://doi.org/10.1108/IJCHM-05-20200480

[10]Curlin, T., Jaković, B., \& Miloloža, I. (2019). Twitter usage in Tourism: Literature Review. Business Systems Research, 10(1), 102-119. https://doi.org/10.2478/bsrj-2019-0008

[11]Dabrowski, D., Brzozowska-Woś, M., Gołąb-Andrzejak, E., \& Firgolska, A.
(2019). Market orientation and hotel performance: The mediating effect of creative marketing programs. Journal of Hospitality and Tourism Management, 41(xxxx), 175-183. https://doi.org/10.1016/j.jhtm.2019.10.006 [12] de Silva, T. M. (2019). Building relationships through customer engagement in Facebook brand pages. Marketing Intelligence and Planning, 38(6), 713-729. https://doi.org/10.1108/MIP-02-20190085

[13] Dwivedi, Y. K., Ismagilova, E., Hughes, D. L., Carlson, J., Filieri, R., Jacobson, J., Jain, V., Karjaluoto, H., Kefi, H., Krishen, A. S., Kumar, V., Rahman, M. M., Raman, R., Rauschnabel, P. A., Rowley, J., Salo, J., Tran, G. A., \& Wang, Y. (2020). Setting the future of digital and social media marketing research: Perspectives and research propositions. International Journal of Information Management, June, 102168.

https://doi.org/10.1016/j.ijinfomgt.2020.1 02168

[14]Efron, S. E., \& Ravid, R. (2019). Writing the literature review : a practical guide.

[15]Faizal, K., \& Abbood, N. (2018). ScienceDirect ScienceDirect Engaging with Customer Using Social Media Platform: A Case Study of Malaysia Hotels. Procedia Computer Science, 124, 4-11.

https://doi.org/10.1016/j.procs.2017.12.12 3

[16] Gupta, V. (2019). The influencing role of social media in the consumer's hotel decision-making process. Worldwide Hospitality and Tourism Themes, 11(4), 378-391.

https://doi.org/10.1108/WHATT-04-20190019

[17] Gustavo, N. (2013). Marketing Management Trends in Tourism and Hospitality Industry: Facing the 21st Century Environment. 5(3), 13-25. https://doi.org/10.5539/ijms.v5n3p13 
[18]Han, Y., \& Lee, H. (2021). Lifestyle Experiences : Exploring Key Attributes of Lifestyle Hotels Using Instagram UserCreated Contents in South Korea.

[19] Hassan, H., Pourabedin, Z., Sade, A. B., \& Chai, J. (2018). Loyalty membership for luxury hotels in Malaysia. International Journal of Tourism Cities, 4(2), 179-193. https://doi.org/10.1108/ijtc-01-2017-0004

[20]Högberg, K. (2017). Challenges of social media marketing - an explorative international study of hotels. 12(2).

[21] Jayawardena, C. C., Horsfield, A., Gellatly, J., Willie, P., \& Sovani, A. (2015). Marketing Canadian hotels in the future.

https://doi.org/10.1108/175542113113141 46

[22] Kalaignanam, K., Tuli, K. R., Kushwaha, T., Lee, L., \& Gal, D. (2021). Marketing Agility: The Concept, Antecedents, and a Research Agenda. Journal of Marketing, $85(1)$, 35-58. https://doi.org/10.1177/002224292095276 0

[23] Kang, J. (2018). Effective marketing outcomes of hotel Facebook pages. Journal of Hospitality and Tourism Insights, 1(2), 106-120. https://doi.org/10.1108/jhti-102017-0003

[24] Koroglu, I. (2019). INSTAGRAM USAGE IN HOSPITALITY SECTOR AS A SOCIAL. 639-653.

[25] Kotler, P., \& Keller, K. L. (2016). Marketing Management Global Edition (Vol.

$15 \mathrm{E})$. https://doi.org/10.1080/089117609030225 56

[26]Le, D. (2018). The Effects of Instagram on Young Foreigners Vacation Choices in Asian Countries .

[27]Leue, M. C., \& Jung, T. (2011). Social Media Marketing in Selected UK Luxury Hotels.

[28]Lin, H. C., Han, X., Lyu, T., Ho, W. H., Xu, Y., Hsieh, T. C., Zhu, L., \& Zhang, L. (2020). Task-technology fit analysis of social media use for marketing in the tourism and hospitality industry: a systematic literature review. International Journal of Contemporary Hospitality Management, 32(8), 2677-2715. https://doi.org/10.1108/IJCHM-12-20191031

[29] Mahmutovic, K. (2021). DEVELOPMENT AND VALIDATION OF THE SCALE FOR MEASURING DIGITAL. February.

[30] Mohammed, A., \& Al-Swidi, A. (2019). The influence of CSR on perceived value, social media and loyalty in the hotel industry. Spanish Journal of Marketing ESIC, 23(3), 373-396. https://doi.org/10.1108/SJME-06-20190029

[31] Nicolaides, A. (2018). Ethical hospitality marketing, brand- boosting and business sustainability. African Journal of Hospitality, Tourism and Leisure, 7(1), 112.

[32] Nuryadin, M. E., \& Mustika, A. (2020). Are Urban Teens Interested in Staying at a Homestay Through Instagram? 5(12), 1043-1048.

[33]Nusair, K. (2020). Developing a comprehensive life cycle framework for social media research in hospitality and tourism: A bibliometric method 20022018. International Journal of Contemporary Hospitality Management, 32(3), 1041-1066. https://doi.org/10.1108/IJCHM-09-20190777

[34] Nusair, K., Butt, I., \& Nikhashemi, S. R. (2019). A bibliometric analysis of social media in hospitality and tourism research. International Journal of Contemporary Hospitality Management, 31(7), 26912719. https://doi.org/10.1108/JJCHM-062018-0489

[35]Papetti, C., Christofle, S., \& GuerrierBuisine, V. (2018). Digital Tools: Their Value and Use for Marketing Purposes. The Emerald Handbook of Entrepreneurship in Tourism, Travel and Hospitality, 277-295. https://doi.org/10.1108/978-1-78743-529220181022 
[36] Parvez, S. J., Moyeenudin, H. M., Arun, S., Anandan, R., \& Janahan, S. K. (2018). Digital marketing in hotel industry. International Journal of Engineering and Technology(UAE), $\quad 7, \quad 288-290$. https://doi.org/10.14419/ijet.v7i2.21.1238 3

[37]Pelsmacker, P. De, Tilburg, S. Van, \& Holthof, C. (2018). International Journal of Hospitality Management Digital marketing strategies, online reviews and hotel performance. International Journal of Hospitality Management, 72(January), 4755.

https://doi.org/10.1016/j.ijhm.2018.01.003

[38] Sabapathy, S. K., \& Selvakumar, J. J. (2018). Impact of Facebook Marketing on E - Word of Mouth : With Reference To the Hotel Industry. 8(116), 116-132.

[39] Sadq, Z. M., Othman, B., \& Khorsheed, R. K. (2019). The impact of tourism marketing in enhancing competitive capabilities. African Journal of Hospitality, Tourism and Leisure, 8(5).

[40] Sibel Mehter AYKIN Akdeniz Üniversitesi İİBF, D., \& Bölümü, İ. (2018). Cilt:3 No:2 Uluslararası Türk Dünyası Turizm Araştırmaları Dergisi. International Journal of Turkic World Tourism Studies, 3(2), 153-170. https://dergipark.org.tr/tr/pub/tdtad/42484 7

[41]Stoychev, I. (2020). Digital and social media marketing strategy. In Digital and Social Media Marketing (pp. 98-120). https://doi.org/10.4324/9780429280689-7

[42] Tanford, S., Kim, M., \& Kim, E. J. (2020). Priming social media and framing causerelated marketing to promote sustainable hotel choice. Journal of Sustainable Tourism, 28(11), 1762-1781. https://doi.org/10.1080/09669582.2020.17 60287

[43] Teare, R. (1990). International Journal of Contemporary Hospitality Management. Marketing Intelligence \& Planning, 8(5), 12-14.
https://doi.org/10.1108/EUM0000000001 079

[44] Terttunen, A., \& Terttunen, A. (2017). The influence of Instagram on consumers , travel plan- ning and destination choice.

[45] Thwala, K. C., \& Slabbert, E. (2018). The effectiveness of the marketing mix for guesthouses. African Journal of Hospitality, Tourism and Leisure, 7(2).

[46] Uğurlu, K. (2020). Integrated Marketing Approach in Hotel Management. The Emerald Handbook of ICT in Tourism and Hospitality, 67-84. https://doi.org/10.1108/978-1-83982-688720201005

[47] Varma, M., Dhakane, N., \& Pawar, A. (2020). Evaluation of impact of instagram on customer preferences: The significance of online marketing. International Journal of Scientific and Technology Research, 9(2), 548-554.

[48] Wibisono, I. P. (2018). Indra Perdana Wibisono Making Digital Marketing Strategies in the Hotel Industry: Case Study of Implementation of New Wave Marketing on Budget Hotel.

[49] Wirtschaft, Z. B. W. L. (2019). Social Media Marketing Efforts of Luxury Brands on Instagram. Expert Journal of Marketing, 7(2), 144-152. 